\title{
The Significance of Economy in the Russian Bi-lateral Treaty Process
}

\author{
David Dusseault ${ }^{1}$, Martin Ejnar Hansen, and Slava Mikhailov
}

\begin{abstract}
:
In his recent article Söderlund (2003) tests structural factors that influence the order in which the Russian regions gained a bi-lateral agreement with the federal centre emphasizing the importance of ethnicity, religion and economy. We replicate his results, and provide an extension where we argue instead that the only significant determinants of the bi-lateral process have been economic issues. Our results are substantiated by an improved methodology that addresses several debatable choices made by the author in the original article.
\end{abstract}

\section{Acknowledgements:}

We would like to thank Peter J. Söderlund for kindly sharing the data used in his article.

\footnotetext{
${ }^{1}$ David Dusseault (contact email dusseaud@tcd.ie) and Slava Mikhailov are with the Department of Political Science, Trinity College Dublin.

Martin Ejnar Hansen is with the Department of Political Science, University of Southern Denmark
} 


\section{Introduction}

From 1994 to 199847 out of Russia's 89 regions signed bi-lateral treaties with the federal centre. Söderlund's article attempted to fill a gap in the political science literature identifying the factors that influenced the success of bi-lateral negotiations. The author claims that the order in which the regions received their bi-lateral treaties has been determined by three factors: the share of titular nationality in a region; whether the titular nationality is Muslim; and relative dependence on federal subsidies. Söderlund supports his elaborations empirically.

However, following Filipov and Shvetsova (1999), we argue that the bi-lateral treaty process, which has characterized the re-creation of the Russian Federation, was predominantly driven by competition for control over economic resources by both regional and federal political elites, with religion and ethnicity playing the role of bargaining tools in this competition. Methodological problems with the original model, identified and addressed in this work, preclude correct identification of the factors influential in determining the nature of the power-relations between the federal centre and the regions in the Russian Federation. Our empirical results support the notion that ethnicity and religion played only secondary role to economy in the bilateral process.

\section{Economy versus Ethnicity}

Söderlund in his 2003 article argues that ethnicity and religion played an equally important role in the bi-lateral treaty negotiation process. Conversely, our view is that it has been an elite centered process in which regional and federal political and economic elites were attempting to forge a new federal system out of the remnants of the Soviet state. Those economic and political residuals blessed and cursed regional and federal leaders with different abilities and resources with which they could establish a new status within the newly bourgeoning Russian state.

The bargaining process that took place between regional and federal elites operated under conditions of great political, economic and social fluidity. Regional leadership was left to defend their interests vis-à-vis the federal centre through the bi-lateral 
negotiating process, using their territorial resources as bargaining chips in the negotiation game. In order to shed some light on the inner workings of this process, we would like to focus our attention on three pertinent questions:

What interests motivated elites at the federal and regional level during the bi-lateral treaty process?

What mechanisms were at their disposal to forward their interests?

What independent variable has the most explanatory power explaining failure or success in the bi-lateral treaty process?

\section{What motivates elites?}

Gerald Alexander (2002) attempted to explain post World War II democratic consolidation in Europe through the use of a soft rational choice approach in which democratic consolidation / non-consolidation depended upon the conservative right elites' perception of their opponents' on the left of the political spectrum behavior and whether or not the right's core values would be protected in the long term by consolidating a democratic regime with their leftist rivals.

Alexander's democratic consolidation paradigm is embedded in a more general construct in which two groups of elites located along a left / right preference distribution axis are competing for their political interests. These interests are not egotistically based; therefore the approach assumes a soft rational choice tack. Each group seeks to maximize its position in relation to its particular induced regime interests, which are determined by their core values.

An explicit power balance will be consolidated between the elites if and when a particular Nash equilibrium is attained and both elite groups are satisfied with the achieved arrangement: interests are maximized and core values are ensured in the long term. 
We believe that this elite value centered model possesses great value in explaining the phenomena of the bi-lateral negotiating process that took place in Russia. Like their counterparts in Post-World War II Western Europe, Russian regional and federal elites were motivated primarily by a core value, that of preservation of their economic and political power. This core value was forwarded by mechanisms, some economic in nature, some political, some ethnically based. We are convinced that there exists a hierarchy of explanatory variables, which are in play with regards to the federal bargaining process.

We believe, contrary to Söderlund, that economic variables are the key in the bilateral process, while ethnicity and religiosity are only means to achieving economic end and therefore have weaker significance in our analysis.

\section{Yeltsin's Federal Reformation}

In response to the collapse of the Soviet System and the rejection of the Communist 'nomenklatura' elite that upheld the system, Yeltsin and his entourage set on a path they term as "Market Bolshevism" in an attempt to destroy the vestiges of the old regime and create a new power base in Russia upon which they could legitimize their political rule. According to Reddaway \& Glinski (2001:35) Yeltsin followed in the footsteps of former Russian leaders as Ivan the Terrible, Peter the Great and Joseph Stalin by trying to create a new class of committed supporters of the regime by redistributing national resources.

With the creation of new elite for the Russian Federation under way, the main task facing the Yeltsin regime was the preservation of Russia's political, economic and territorial integrity. Bi-lateral agreements were signed between Moscow and the regional units, with some contravening the new federal Constitution and mostly giving measurable amounts of political and economic autonomy thus creating the foundations for centers of political and economic power that rivaled Moscow.

Out of the chaos of the collapse of the Soviet Union and the re-forging of the Russian Federation emerged a visibly pronounced elite grouping: those in Moscow and those 
in the regions. The new elites possess a set of core values that inspire their regime preference:

“After Putin's election, the mood of Russia's political and economic elite comprised two main emotions. They were almightily relieved that they and their wealth and power had survived through the chaotic last years of the ailing Yeltsin's erratic, roller coaster rule. But they were also desperately anxious that this wealth and power be secured and guaranteed, that the state and the elite be consolidated and strengthened after all the confrontations and dislocations of the Yeltsin years. They wanted all-round consolidation, but not at the price of any major new conflict." (Reddaway and Ortung 2003:12-13)

The new elites in both the federal centre in Moscow and the regions are concerned with the preservation of their wealth and political power. According to Alexander (2002), the variation in their preferred regime type develops out of the desire to maximize the benefits and minimize the costs in defense of these core values.

\section{The Mechanisms}

How did elites then contest their preferences and protect their economic and political power? Robert Ortung has published two influential articles both in the EWI Russian Regional Report identifying the mechanisms at work during the process of federal creation in Russia.

In the first article, Ortung (2000a) identified ten tools with which the Kremlin was able to counteract or influence control over the regional governors. The mechanisms outlined are as follows:

- Federal budgetary largess: under Yeltsin buying-off opponents, under Putin rewarding allies;

- Regional differentiation: cleavages and disproportionality of the regions in many factors such as economic production, proximity to Moscow all add up to a divide and rule political weapon for Moscow; 
- Kremlin support for regional gubernatorial campaigns: ability to support or undercut a specific candidate's political aspirations;

- Distribution of federal funds: the granting of export-import privileges along with tax loop-holes to aid business development in certain regions;

- Natural state owned monopolies: possess the ability to control access to and levy tariffs on resources such as transport of goods and electricity;

- Presidential representative in federal districts: active representatives to the President of the Federation that acts as the eyes and ears of his administration in the regions;

- Bi-lateral agreements: signed with 46 regions, included political and economic "strong incentives" to stay within the federal structure;

- Federal removal of regional executives: the removal of any regional executive found to be in violation of Russian Criminal and Constitutional Law; and

- Limits of governors' terms in office: no more than two 5-year terms in a row are to be served by an individual.

In the second part of the article (Ortung 2000b), Ortung illustrates just what mechanisms the governors have at their disposal to counterbalance the political and economic might of the Kremlin. Far from being superficial in nature, due to Soviet political legacy, the nature of the bi-lateral agreements, the strongman nature of Russian regional politics and the economic sink or swim mentality in the regions after the 1998 crash, Ortung reveals five instruments at the governors' disposal:

- Extensive control over the local economy and resources: many governors have very good connections with regional businesses;

- Control of institutional resources translates into political power: utilizing their regional power base, governors have the ability to influence political campaigns at all levels of the political hierarchy sometimes ensuring reelection for themselves and a cadre of representatives at all levels of government competing in the region's interest; 
- Circumvention of federal bureaucracies in the regions: governors may be truant in their supply, delivery and cooperation with federal representatives on their turf;

- Use of soft budgetary constraints: barter, loans, creative accounting all can be used to disguise how the regional treasury is being utilized or manipulated; and

- Regional filibuster: using political clout to block the passage of federally initiated directives or policies.

The majority of these mechanisms are economically based. By utilizing the economic means at their disposal, federal and regional elites attempted to hammer out agreements that suited their particular preferences.

The preponderance of economic mechanisms in use directly ties in with the work of Dowley (1998) in which elites possess certain strategies to secure a favorable federal arrangement for their territory. The instrumental perspective allows room for a rational economic approach to deciphering the bi-lateral agreement process in place of an ethnically based view. Ethnicity can be created to suit the prevailing conditions at the time of conflict. Elites manipulate the issue of nationality to satisfy a more central goal.

In many republics at the time of the collapse of the USSR and the re-working of the Soviet federal system, many issues that were brought up by autonomous republics were of an economic nature as embodied in the bi-lateral agreement signed by Sakha. As Dowley (1998:363) points out, there seems to be some credibility in the alternative that posits purely rent-seeking behavior by the regional elites. Governors of resource rich states would be more likely to demand autonomy and potential independence from Moscow in the pursuit of capturing greater rent from the regional resources than was previously sought.

According to the instrumentalist models then, ethnicity as an essential explanatory variable in the bi-lateral treaty process is relegated to a less significant position. This judgment is substantiated by the logic that ethnicity is not a value of the elites, but a 
mechanism that will help them achieve their ultimate goal of a regionally specific level of economic and political autonomy in relation to the federal centre.

If we assume that elites are rationally driven actors then ethnicity is less than stable value to espouse due to the fact that a high level of ethnic nationalism would be very expensive and would inevitably draw resources away from political and economic power of the region. Also in a system in which ethnicity was engineered and manipulated to serve politically expedient needs of the state, we would expect that there would be higher and lower levels of ethnicity; the measurement of which would be very difficult indeed.

Still, for the sake of argument, in regions where latent levels of radical ethnonationalism existed, such as Chechnya, an ethnic republic was not the core value espoused by elites, but a high degree of economic and political autonomy from the federal centre. Ethnicity was an astute bargaining chip however overplayed by the Chechen elite. Authors such as Tishkov (1997) in his analysis of the Chechen conflict point to the difficulty of identifying the direct or indirect affect the ethnicity variable will have on the bargaining game. Tishkov describes a process in which ethnicity is an instrument utilized by elites to achieve their economic and political goals. Ethnicity in itself does not exist separate from other variables, but is intertwined with them.

\section{Empirical Analysis}

The methodology used in the original article raises several questions. First and foremost is Söderlund's choice of ordinary least squares (OLS) for estimation of his model. The author admits that his dependent variable is a time-index, yet he fails to address any of the problems associated with using 'time' as a dependent variable. Apart from the obvious problem of right censoring, the author's approach assumes the residuals to be normally distributed as part of the classical linear model assumptions. Cleves, Gould, and Gutierrez (2004: 2) argue that this assumption represents the biggest problem in using the OLS with the time-index dependent variable. In particular, there is no reason to suspect that the time elapsed between different regional treaties signed is normally distributed. Intuitively it makes more sense for the distribution of the timing of bi-lateral treaties signed to be non-symmetric, and even 
bimodal. As Cleves et al (2004: 2) note, results estimated with OLS under these conditions will not be robust. This point is also emphasized by Wooldridge (2002: 524-525) who shows that in these situation OLS estimation of the slope coefficient is inconsistent.

Instead, a duration model would be more appropriate. Immediate problem concerns the arbitrariness of the starting point of the timing index constructed by Söderlund (2002) who chose the date of the first treaty signed as the starting point. As Filipov and Shvetsova (1999) indicate, the beginning of the bi-lateral negotiating process was premeditated and formalized in 1990, and not 1994, with the federal units receiving bi-lateral treaties being the units that were specifically targeted already by the late Soviet period political elite for bi-lateral agreements. Hence it is rather difficult to estimate a correct starting point for the timing index.

Although Söderlund's choice of the starting point affects only the value of the intercept point in his original OLS estimation, it poses a significant problem for parametric duration model estimation. At the same time, semi-parametric models, like the Cox proportional hazard model, are determined only by the matching and ordering of the time of signing of the bi-lateral agreements. In such models time is used only to order the data with no special meaning attached to the starting point. As noted by Cleves et al (2004: 22), semi-parametric modeling, and the Cox proportional hazard model in particular, amounts to a combination of "individual binary-outcome analyses at each of the failure times", where "failure time" would be the time of treaty signing.

As discussed above, the bi-lateral agreement process started in the later period of USSR and long before the first treaty was signed with Tatarstan in 1994. Related to this issue is the fact that the constituent units that made up the Soviet Union, such as union republics and autonomous units of these republics possessed differing degrees of economic and also political resources within the hierarchy of political units. Despite being considered units within union republics, autonomous republics were equally represented at the higher echelons of power and were de facto if not de jure of equal status to the union republics. An example stems from the composition of the Central Committee of the Soviet Union in 1986, more than half of its 300 full members represented different levels of federation members. 
This situation was quite unique in the Soviet system and allowed more or less equal representation for regional interests in Moscow (Filipov and Shvetsova 1999: ). Hence when Russian federal centre officials found themselves at the bi-lateral agreements negotiations they faced different types of regions, some of them, following the tradition of equal representation at the CPSU Central Committee, feeling in no way inferior to the newly created federal centre. Thus we believe that autonomous status of a region within the Federation had a major influence in determining whether the regions received bi-lateral agreements and when they were signed. An autonomous status of a region is measured using a dichotomous variable from the original data provided by Söderlund, which divides the sample into autonomous republics and other types of regions (e.g. krais, oblasts, etc). For our Cox proportional hazard model this implies using a stratified estimation where baseline hazard will vary according to the type of autonomy enjoyed by regions.

Some of the variables used in the original analysis were re-coded in the replication according to the convention, affecting only the presentation of the results (e.g. fractions were used instead of percentages). Moreover, in the replication we used a $\log$ distance instead of the raw number of kilometers from the region administrative capital to Moscow as the former is almost normally distributed while the latter is significantly skewed to the left. Also with the proxy variable for economic dependence Söderlund (2003: 319-20) follows McAuley (1997). Yet McAuley (1997, 433-434) used the "share of receipts from federal budget in total budget revenue of regions" and not the share of regional budget without federal subsidies. Replication follows the original McAuley (1997) approach, as we believe it makes more intuitive sense in evaluating the economic dependence of the region on the federal centre.

We also re-evaluate Söderlund's treatment of ethnicity within federal units. $\mathrm{He}$ measures ethnicity by the share of titular nationality in the region with values given only for 20 out of 80 regions in the dataset. We believe that due to a complex federal structure of Russia, the share of titular nationality by itself does not provide adequate information on ethnic fractionalization. In the absence of necessary data in the original article to compose an ethnic fractionalization index following Alesina, Devleeschauwer, Easterly, Kurlat, and Wacziarg (2002) the share of Russians in a 
region in combination with the share of titular nationality should provide a reasonable approximation of the ethnicity measure.

The aim of this paper, as well as Söderlund's (2002) original research, is to identify the variables that influenced the timing of the bi-lateral agreements. The robustness of the results can be evaluated through an alternative specification, by asking what influenced whether a region was successful or not in securing a bi-lateral treaty. This alternative specification is estimated using a logit regression. The influence of the status of autonomy is estimated in this model using a dummy variable provided by Söderlund (2002).

Our analysis shows that dependence or independence of federal subsidies is the only significant determinant in bi-lateral process in all specifications. Ethnicity also plays a prominent role, although it is not robust to model specification, with logit estimates of ethnicity being marginally insignificant at the conventional .05 significance level. Moreover, contrary to Söderlund's results we find that whether a region is predominantly Muslim had no effect on the outcome of negotiation process between the regions and the centre.

The first column of results in Table 1 presents estimates of Söderlund's (2003) original model. The second column shows results for Cox proportional hazard model with ethnicity defined only by the share of titular nationality in the population of the region. Next we estimate the same model adding the share of Russian population in the region. Followed by a stratified Cox model accounting for different baseline hazard according to the type of autonomy enjoyed by the region. Robustness of our results is estimated using two specifications of a logit regression, with the second accounting for a regional autonomy status through a dummy variable available in Söderlund's original data.

We also present results of a link test for the specification of the dependent variable following Tukey (1949) further developed by Pregibon (1980). And a proportionality test $\ldots .$.

\section{Concluding remarks}


This paper attempted to review the structural factors that influenced the timing of the bi-lateral treaties in Russia identified in the literature. We also provide empirical evidence for the argument that, contrary to the views presented in the mass media and supported by Söderlund, ethnicity and religion play at best only secondary role to economic issues in the relations between the federal centre and the regions in Russia. Further research on the issue utilizing improved data with correctly constructed ethnicity and religion variables following Alesina et al (2002) can provide empirical evidence on the nature of some conflicts between the centre and the regions in modern Russia with Chechnya being the most obvious example. 
Table 1.

\begin{tabular}{|c|c|c|c|c|c|c|}
\hline \multirow[t]{2}{*}{ Variables } & \multirow[t]{2}{*}{ OLS } & \multicolumn{2}{|c|}{$\begin{array}{l}\text { Cox } \\
\text { Hazard Ratio }\end{array}$} & \multirow{2}{*}{$\begin{array}{l}\text { Stratified } \\
\text { Cox } \\
\text { Hazard } \\
\text { Ratio }\end{array}$} & \multirow[t]{2}{*}{ Logit } & \multirow{2}{*}{$\begin{array}{l}\text { Logit with } \\
\text { regional } \\
\text { status } \\
\text { dummy }\end{array}$} \\
\hline & & $\begin{array}{l}\text { Original } \\
\text { Model }\end{array}$ & $\begin{array}{l}\text { Modified } \\
\text { Model }\end{array}$ & & & \\
\hline $\begin{array}{l}\text { Share of titular } \\
\text { nationality }\end{array}$ & $\begin{array}{l}1.590 \\
(.443) \\
0.001\end{array}$ & $\begin{array}{l}29.758 \\
(33.986) \\
0.003\end{array}$ & $\begin{array}{l}.212 \\
(.490) \\
0.502\end{array}$ & $\begin{array}{l}.225 \\
(.571) \\
0.556\end{array}$ & $\begin{array}{l}-3.54 \\
(4.472) \\
0.428\end{array}$ & $\begin{array}{l}-.728 \\
(5.152) \\
0.888\end{array}$ \\
\hline Muslim dummy & $\begin{array}{l}85.639 \\
(29.548) \\
0.006\end{array}$ & $\begin{array}{l}1.037 \\
(.932) \\
0.967\end{array}$ & $\begin{array}{l}.754 \\
(.667) \\
0.749\end{array}$ & $\begin{array}{l}.915 \\
(.813) \\
0.920\end{array}$ & $\begin{array}{l}-1.12 \\
(1.369) \\
0.413\end{array}$ & $\begin{array}{l}-1.377 \\
(1.471) \\
0.349\end{array}$ \\
\hline $\begin{array}{l}\text { Budget } \\
\text { subsidies }^{3}\end{array}$ & $\begin{array}{l}1.719 \\
(.631) \\
0.010\end{array}$ & $\begin{array}{l}.004 \\
(.006) \\
0.000\end{array}$ & $\begin{array}{l}.004 \\
(.007) \\
0.000\end{array}$ & $\begin{array}{l}.010 \\
(.014) \\
0.001\end{array}$ & $\begin{array}{l}-6.527 \\
(2.169) \\
0.003\end{array}$ & $\begin{array}{l}-6.953 \\
(2.277) \\
0.002\end{array}$ \\
\hline $\begin{array}{ll}\begin{array}{l}\text { Distance } \\
\text { Moscow }^{4}\end{array} & \text { from } \\
\end{array}$ & $\begin{array}{l}.007 \\
(.004) \\
0.099 \\
\end{array}$ & $\begin{array}{l}1.366 \\
(.232) \\
0.066\end{array}$ & $\begin{array}{l}1.143 \\
(.227) \\
0.499\end{array}$ & $\begin{array}{l}1.114 \\
(.221) \\
0.587\end{array}$ & $\begin{array}{l}.024 \\
(.308) \\
0.938\end{array}$ & $\begin{array}{l}.054 \\
(.311) \\
0.863\end{array}$ \\
\hline Border/port & $\begin{array}{l}31.125 \\
(15.188) \\
0.048\end{array}$ & $\begin{array}{l}1.143 \\
(.387) \\
0.694\end{array}$ & $\begin{array}{l}.996 \\
(.339) \\
0.990\end{array}$ & $\begin{array}{l}1.129 \\
(.388) \\
0.724\end{array}$ & $\begin{array}{l}.098 \\
(.560) \\
0.861\end{array}$ & $\begin{array}{l}.044 \\
(.566) \\
0.938\end{array}$ \\
\hline $\begin{array}{ll}\text { Share } & \text { of } \\
\text { Russians }\end{array}$ & & & $\begin{array}{l}.005 \\
(.011) \\
.017\end{array}$ & $\begin{array}{l}.009 \\
(.02) \\
0.033\end{array}$ & $\begin{array}{l}-7.812 \\
(4.321) \\
0.071\end{array}$ & $\begin{array}{l}-8.179 \\
(4.329) \\
0.059\end{array}$ \\
\hline $\begin{array}{l}\text { Regional Status } \\
\text { dummy }\end{array}$ & & & & & & $\begin{array}{l}-1.413 \\
(1.343) \\
0.293\end{array}$ \\
\hline Constant & $\begin{array}{l}-105.609 \\
(59.566) \\
0.085\end{array}$ & & & & $\begin{array}{l}8.996 \\
(5.486) \\
0.101\end{array}$ & $\begin{array}{l}9.537 \\
(5.617) \\
0.090\end{array}$ \\
\hline $\begin{array}{l}\text { Link test for } \\
\text { model } \\
\text { specification } \\
\text { P value }\end{array}$ & & $\begin{array}{l}0.174 \\
\text { passed }\end{array}$ & $\begin{array}{l}0.079 \\
\text { passed }\end{array}$ & $\begin{array}{l}0.087 \\
\text { passed }\end{array}$ & $\begin{array}{l}0.148 \\
\text { passed }\end{array}$ & $\begin{array}{l}0.105 \\
\text { passed }\end{array}$ \\
\hline $\begin{array}{l}\text { Test of the } \\
\text { proportional } \\
\text { hazard } \\
\text { assumption } \\
\text { Chi sq (P value) }\end{array}$ & & $\begin{array}{l}22.55 \\
0.0004 \\
\text { failed }\end{array}$ & $\begin{array}{l}18.59 \\
0.0049 \\
\text { failed }\end{array}$ & $\begin{array}{l}10.04 \\
0.1228 \\
\text { passed }\end{array}$ & & \\
\hline $\begin{array}{l}\text { Adj. } \mathrm{R}^{2} / \text { Pseudo } \\
\mathrm{R}^{2}\end{array}$ & .502 & & & & 0.1557 & 0.1664 \\
\hline Log Likelihood & & -152.186 & -149.603 & -131.056 & -44.277 & -43.713 \\
\hline LR & & 17.20 & 22.37 & 17.59 & 16.33 & 17.46 \\
\hline$p$-value & & 0.0041 & 0.0010 & 0.0074 & 0.0121 & 0.0147 \\
\hline $\mathrm{N}$ & 42 & 75 & 75 & 75 & 76 & 76 \\
\hline
\end{tabular}

First number in the cells is the coefficient. Second the standard errors. Third the pvalue.

\footnotetext{
${ }^{2}$ As discussed above we express the share of titular nationality and the share of Russians as a proportion instead of raw percentages used by Söderlund (2003).

${ }^{3}$ Independence of subsidies in original specification, and dependence on subsidies in our replication.

${ }^{4}$ Distance in kilometres in original specification and log distance in replication.
} 


\section{References}

Alesina, A., A. Devleeschauwer, W. Easterly, S. Kurlat, and R. Wacziarg (2002): Fractionalization. National Bureau of Economic Research. NBER Working Paper No. 9411. Cambridge, MA.

Alexander, G. (2000): The Sources of Democratic Consolidation Cornell University Press

Cleves, M., W. Gould, and R. Gutierrez (2004): An Introduction to Survival Analysis Using Stata. Revised edition. College Station, TX: Stata Press.

Dowley, K. M. (1999): “Striking the federal bargain in Russia: Comparative regional government strategies," Communist and Post-Communist Studies 31(4), pp. 359-379

Filipov M. and O. Shvetsova (1999): "Asymmetric bilateral bargaining in the new Russian Federation. A path-dependence explanation," Communist and PostCommunist Studies 32(1), pp. 61-76

McAuley, A. (1997): “The determinants of Russian federal-regional fiscal relations: Equity or political influence," Europe-Asia Studies 49(3), pp. 431-444

Ortung, R. (2000a): “Centre-Periphery Relations: Kremlin has Many Tools to Keep Even Elected Governors in Check," EWI Russian Regional Report Vol. 5 No. 80103

Ortung, R. (2000b): "Centre-Periphery Relations: Resourceful Governors Able to Counter Kremlin,” EWI Russian Regional Report Vol. 5 No. 1015.03

Pregibon, D. (1980): “Goodness of link tests for generalized linear models," Applied Statistics 29, pp. 15-24. 
Reddaway, P. and D. Glinski (2001): The Tragedy of Russia's Reforms. Washington: Institute of Peace Press

Reddaway P. \& R. Ortung (2003): The Dynamics of Russian Politics: Putin's Reforms of Federal-Regional Reforms.

Söderlund, P. J. (2003): “The significance of structural power resources in the Russian Bi-lateral treaty process 1994-1998," Communist and Post-Communist Studies 36, pp. 311-324.

Tishkov, V. A. (1997): Ethnicity, Nationalism and Conflict in and after the Soviet Union: the Mind Aflame SAGE: London

Tukey, J.W. (1949): “One degree of freedom for non-additivity," Biometrics 5, pp. 232-242.

Wooldridge, J. (2002): Econometric analysis of cross section and panel data. Cambridge, MA.: MIT Press. 